\title{
Insights into the vanadia catalyzed oxidative dehydrogenation of isobutane with $\mathrm{CO}_{2}$
}

\author{
Ruixue Yuan a, Yang Li ${ }^{b}$, Haobing Yan a, Huan Wang a, Jian Song c, Zhongshen Zhang b, Weibin Fan c, \\ Jiangang Chen a, Zhongwen Liu a,*, Zhaotie Liu a , Zhengping Hao b,\# \\ a Key Laboratory of Applied Surface and Colloid Chemistry, School of Chemistry \& Chemical Engineering, Shaanxi Normal University, Xi'an 710062, \\ Shaanxi, China \\ b Department of Environmental Nano-materials, Research Center for Eco-Environmental Sciences, Chinese Academy of Sciences, Beijing 100085, China \\ c State Key Laboratory of Coal Conversion, Institute of Coal Chemistry, Chinese Academy of Sciences, Taiyuan 030001, Shanxi, China
}

A R T I C L E I N F O

Article history:

Received 21 June 2014

Accepted 26 June 2014

Published 20 August 2014

\section{Keywords:}

Isobutane

Oxidative dehydrogenation

Carbon dioxide

Vanadia

Alumina

\begin{abstract}
A B S T R A C T
Vanadia-based catalysts were prepared using the sol-gel method and were subjected to the oxidative dehydrogenation of isobutane with $\mathrm{CO}_{2}$. The materials were extensively characterized by using $\mathrm{X}$-ray diffraction, $\mathrm{N}_{2}$ adsorption-desorption, $\mathrm{O}_{2}$-temperature programmed oxidation, temperature programmed surface reaction, and in situ Fourier transform infrared techniques. Catalytic results indicate that a high selectivity toward total $\mathrm{C}_{4}$ olefins over $85 \%$ was obtained over all of the catalysts. On the contrary, the highest conversion of isobutane was observed over $12 \mathrm{wt} \%$ $\mathrm{V}_{2} \mathrm{O}_{5} / \mathrm{Ce}_{0.6} \mathrm{Zr}_{0.4} \mathrm{O}_{2}(7 \mathrm{wt} \%)-\mathrm{Al}_{2} \mathrm{O}_{3}$, and a more stable performance was achieved over $6 \mathrm{wt} \%$ $\mathrm{V}_{2} \mathrm{O}_{5}-\mathrm{Ce}_{0.6} \mathrm{Zr}_{0.4} \mathrm{O}_{2}(7 \mathrm{wt} \%)-\mathrm{Al}_{2} \mathrm{O}_{3}$. The catalytic activity for the titled reaction was found to be dependent on the dispersion and crystallinity of the $\mathrm{VO}_{x}$ species over the catalyst, and the deposition of the heavier coke over the catalyst was revealed to be the main reason for the catalyst deactivation. Moreover, the benefit of $\mathrm{CO}_{2}$ toward the titled reaction was clearly revealed from TPSR results, and the reaction was confirmed to follow the redox mechanism.
\end{abstract}

(C) 2014, Dalian Institute of Chemical Physics, Chinese Academy of Sciences. Published by Elsevier B.V. All rights reserved.

\section{Introduction}

Light alkanes $\left(\mathrm{C}_{2}-\mathrm{C}_{4}\right)$ are important and versatile building blocks for the industrial production of various chemicals and plastics [1-3]. Because the byproducts of steam cracking and fluidized catalytic cracking of naphtha cannot provide sufficient light alkenes for the expanding market, the catalytic dehydrogenation of light alkanes to their respective olefins has received much attention over the last few decades. However, to obtain a reasonably high conversion, the dehydrogenation of light al- kanes can only be performed at high temperatures because of the endothermic nature of this reaction. As a result, drawbacks such as high energy consumption, low selectivity toward the desired light olefin, and accelerated catalyst deactivation are apparent since thermal cracking reactions are favored at high reaction temperatures [4]. To overcome these obstacles, oxidative dehydrogenation with molecular oxygen has been proposed, and much work has been conducted [5-7]. Its exothermic property makes the oxidative dehydrogenation reaction thermodynamically favorable at low temperatures. However,

\footnotetext{
* Corresponding author. Tel: +86-29-81530801; Fax: +86-29-81530727; E-mail: zwliu@snnu.edu.cn

\# Corresponding author. Tel/Fax: +86-10-62923564; E-mail: zpinghao@rcees.ac.cn

This work was supported by the National Basic Research Program of China (973 Program, 2010CB732300) and the National Natural Science Foundation of China (21376146, 21306111, 21337003). DOI: 10.1016/S1872-2067(14)60180-7 | http://www.sciencedirect.com/science/journal/18722067 | Chin. J. Catal., Vol. 35, No. 8, August 2014
} 
the inherent oxidation property of molecular oxygen makes this process challengeable with regard to olefin selectivity because of the unavoidable oxidation of hydrocarbons to $\mathrm{CO}_{2}$. Additionally, process control difficulties are encountered because of potential flammability and heat removal difficulties. As an alternative, soft oxidants such as $\mathrm{N}_{2} \mathrm{O}$ and $\mathrm{CO}_{2}$ can replace molecular oxygen and they offer a potentially attractive route for the dehydrogenation of light alkanes to alkenes.

In recent years, the use of $\mathrm{CO}_{2}$ as a soft oxidant has received much attention, as green chemistry has developed and raised concerns about its greenhouse effect $[8,9]$. Compared with molecular oxygen, $\mathrm{CO}_{2}$ is a nonconventional oxidant, and has obvious advantages such as minimizing the deep oxidation of hydrocarbons, enhancing the selectivity of targeted olefins, and alleviating $\mathrm{CO}_{2}$ emissions $[9,10]$. As clearly expressed in related papers [11-20], the oxidative dehydrogenation of light alkanes and ethylbenzene with $\mathrm{CO}_{2}$ is one of the main trends in the catalytic domain.

In principle, the oxide catalysts developed for oxidative dehydrogenation with molecular oxygen are also active when using $\mathrm{CO}_{2}$ as an oxidant. This has been unambiguously confirmed in the literature. However, analyses of the reported results indicate that much work is still required for the development of a high-performance catalyst for the oxidative dehydrogenation of light alkanes with $\mathrm{CO}_{2}$ because of its much lower activity. The mechanism for the oxidative dehydrogenation of light alkanes with $\mathrm{CO}_{2}$ has not been thoroughly explained although different pathways have been proposed, i.e., a one-step process following the Mars-van Krevelen mechanism and the coupled process of the direct dehydrogenation and reverse water-gas-shift reaction $[11,17,21]$. The redox and acid-base properties of oxides make the differentiation between the two pathways challenging. Therefore, the development of a high-performance catalyst based on a mechanistic understanding is desirable although different oxides such as $\mathrm{V}_{2} \mathrm{O}_{5}$ [22], $\mathrm{CeO}_{2}[23,24], \mathrm{Zr}_{2} \mathrm{O}_{3}[25,26], \mathrm{Gd}_{2} \mathrm{O}_{3}[27,28], \mathrm{MoO}_{3}[29,30], \mathrm{La}_{2} \mathrm{O}_{3}$ [31] and $\mathrm{In}_{2} \mathrm{O}_{3}[32,33]$ have been quantitatively investigated for the oxidative dehydrogenation of light alkanes with $\mathrm{CO}_{2}$.

In previous works [34,35], we proposed the use of the $\mathrm{Ce}^{3+}-\mathrm{Ce}^{4+}$ redox couple to inhibit the deep reduction of $\mathrm{V}^{5+}$ as a new idea for catalyst design toward the oxidative dehydrogenation of ethylbenzene with $\mathrm{CO}_{2}$ [35]. A highly active and stable catalyst $\left(\mathrm{V}_{2} \mathrm{O}_{5} / \mathrm{Ce}_{0.6} \mathrm{Zr}_{0.4} \mathrm{O}_{2}-\mathrm{Al}_{2} \mathrm{O}_{3}\right)$ was obtained [34]. In this work, $\mathrm{V}_{2} \mathrm{O}_{5} / \mathrm{Ce}_{0.6} \mathrm{Zr}_{0.4} \mathrm{O}_{2}-\mathrm{Al}_{2} \mathrm{O}_{3}$ and $\mathrm{V}_{2} \mathrm{O}_{5}-\mathrm{Ce}_{0.6} \mathrm{Zr}_{0.4} \mathrm{O}_{2}-\mathrm{Al}_{2} \mathrm{O}_{3}$ catalysts were comparatively investigated for the oxidative dehydrogenation of isobutane with $\mathrm{CO}_{2}\left(\mathrm{CO}_{2}-\mathrm{ODB}\right)$. Reaction results confirmed the validity of our idea for the design of a suitable catalyst for oxidative dehydrogenation reactions with $\mathrm{CO}_{2}$. The effect of catalyst composition on the conversion of isobutane and the selectivity of butenes was confirmed by characterization results. Moreover, the role of $\mathrm{CO}_{2}$ in the titled reaction was clear from the results of temperature-programmed surface reaction (TPSR) and in situ Fourier transform infrared spectroscopy (FTIR).

\section{Experimental}

\subsection{Catalyst preparation}

The catalysts were prepared by a modified sol-gel method using aluminum isopropoxide, cerium nitrate, zirconium nitrate, and ammonium metavanadate as the oxide precursor of $\mathrm{Al}, \mathrm{Ce}, \mathrm{Zr}$, and $\mathrm{V}$, respectively. The experimental procedure was as follows for the preparation of $\mathrm{Ce}_{0.6} \mathrm{Zr}_{0.4} \mathrm{O}_{2}$ (7 wt\%) $-\mathrm{Al}_{2} \mathrm{O}_{3}$ (CZA). A predetermined amount of aluminum isopropoxide was dissolved in a mixture of toluene and ethanol at a volume ratio of 1 for the preparation of $1.5 \mathrm{~mol} \cdot \mathrm{L}^{-1}$ aluminum solution (Solution A). After dissolving cerium nitrate and zirconium nitrate at a $\mathrm{Ce} / \mathrm{Zr}$ molar ratio of $6 / 4 \mathrm{in} 30 \mathrm{~mL}$ absolute ethanol, a $0.1 \mathrm{~mol} \cdot \mathrm{L}^{-1}$ cation solution was obtained (Solution B). At room temperature, predetermined volumes of solutions $\mathrm{A}$ and $\mathrm{B}$ were thoroughly mixed, and vigorously stirred for $1 \mathrm{~h}$. The mixture was then refluxed at $85{ }^{\circ} \mathrm{C}$ for $3 \mathrm{~h}$, and aged for $12 \mathrm{~h}$. After this, the solvent was evaporated at $50^{\circ} \mathrm{C}$. Finally, CZA was obtained by drying and calcining the solid at $110{ }^{\circ} \mathrm{C}$ for $8 \mathrm{~h}$ and at $550^{\circ} \mathrm{C}$ for $4 \mathrm{~h}$, respectively.

For the $\mathrm{V}_{2} \mathrm{O}_{5}$-supported catalysts, an aqueous solution of $\mathrm{NH}_{4} \mathrm{VO}_{3}$ along with oxalic acid was impregnated into CZA via the incipient wetness method. After drying and calcining the solid at $110{ }^{\circ} \mathrm{C}$ for $8 \mathrm{~h}$ and $550{ }^{\circ} \mathrm{C}$ for $4 \mathrm{~h}$, respectively, $\mathrm{V}_{2} \mathrm{O}_{5} / \mathrm{CZA}$ with different vanadia loadings was obtained.

Following the same method for the preparation of CZA, the desired amount of $\mathrm{NH}_{4} \mathrm{VO}_{3}$ was added to the mixture and $\mathrm{V}_{2} \mathrm{O}_{5}(x$ wt $\%)-\mathrm{Ce}_{0.6} \mathrm{Zr}_{0.4} \mathrm{O}_{2}(7 \mathrm{wt} \%)-\mathrm{Al}_{2} \mathrm{O}_{3}$ with varied vanadia content was obtained after drying and calcining under the same conditions. For brevity, the $\mathrm{V}_{2} \mathrm{O}_{5}\left(x \quad\right.$ wt\%)-Ce0.6 $\mathrm{Zr}_{0.4} \mathrm{O}_{2}(7$ wt\%) $-\mathrm{Al}_{2} \mathrm{O}_{3}$ catalysts are designated $x$-VCZA, where $x$ represents the weight content of $\mathrm{V}_{2} \mathrm{O}_{5}$.

\subsection{Catalyst characterization}

$\mathrm{N}_{2}$ adsorption-desorption isotherms were measured on a Tristar 3000 (Micromeritics) at $-196^{\circ} \mathrm{C}$. The BET method was used to calculate the specific surface area of the materials. Before an analysis, the sample was degassed at $300{ }^{\circ} \mathrm{C}$ for $6 \mathrm{~h}$ to remove any contaminants and physisorbed moisture.

Powder X-ray diffraction (XRD) data were collected on an X-ray diffractometer (Bruker AXS D8) using monochromatic $\mathrm{Cu} / K_{\alpha}$ radiation at $40 \mathrm{kV}$ and $40 \mathrm{~mA}$ and a scan rate of $2^{\circ} \cdot \mathrm{min}^{-1}$.

Temperature-programmed desorption of carbon dioxide ( $\mathrm{CO}_{2}$-TPD) was performed on a Micromeritics AutoChem II 2920 instrument. A $50.0 \mathrm{mg}$ (40-60 mesh) sample was loaded into a quartz reactor and pretreated at $550{ }^{\circ} \mathrm{C}$ for $1 \mathrm{~h}$ under an argon flow of $35 \mathrm{~mL} \cdot \mathrm{min}^{-1}$. After cooling to $60^{\circ} \mathrm{C}, \mathrm{CO}_{2}$ was pulsed until saturated adsorption was achieved. To remove the physically adsorbed $\mathrm{CO}_{2}$, the reactor was purged with argon for $1 \mathrm{~h} . \mathrm{CO}_{2}$-TPD was then carried out from 60 to $550{ }^{\circ} \mathrm{C}$ at a heating rate of $10{ }^{\circ} \mathrm{C} \cdot \mathrm{min}^{-1}$, and the desorbed $\mathrm{CO}_{2}$ was monitored with a thermal conductivity detector (TCD).

Temperature-programmed oxidation of oxygen $\left(\mathrm{O}_{2}\right.$-TPO) was carried out on a TL 5000-II instrument (Xianquan Industry and Trade Development Co., Ltd., China) equipped with a mass spectroscope (Omni Star 200). The catalyst sample (50.0 mg) was pretreated under argon at $200{ }^{\circ} \mathrm{C}$ for $1 \mathrm{~h}$. After cooling to $30{ }^{\circ} \mathrm{C}, 5 \% \mathrm{O}_{2}$ in $\mathrm{Ar}$ at a flow rate of $30 \mathrm{~mL} \cdot \mathrm{min}^{-1}$ was applied and $\mathrm{O}_{2}$-TPO was carried out from 30 to $900{ }^{\circ} \mathrm{C}$ at a ramp up 
rate of $5{ }^{\circ} \mathrm{C} \cdot \mathrm{min}^{-1}$. The produced $\mathrm{CO}_{2}$ was monitored using a mass spectrometer.

The amount of coke deposited on the used catalysts was determined using a thermogravimetric analyzer (Thermo Plus EVO, Rigaku). The sample was heated under an air atmosphere from 30 to $800{ }^{\circ} \mathrm{C}$ at a ramp up rate of $10^{\circ} \mathrm{C} \cdot \mathrm{min}^{-1}$.

TPSR was performed in a fixed bed reactor connected to a mass spectroscope (Omni Star 200). The catalyst was pretreated at $200{ }^{\circ} \mathrm{C}$ for $1 \mathrm{~h}$ under nitrogen flow. After cooling to $30{ }^{\circ} \mathrm{C}$, a $30 \mathrm{~mL} \cdot \mathrm{min}^{-1}$ flow of $\mathrm{CO}_{2}$ (or $\mathrm{N}_{2}$ ) $/ \mathrm{C}_{4} \mathrm{H}_{10}$ at a molar ratio of 5 was used, and the sample was heated to $700{ }^{\circ} \mathrm{C}$ at a ramp up rate of $5{ }^{\circ} \mathrm{C}$ per minute.

In situ FTIR spectra were obtained on a Bruker TENSOR 27 spectrometer equipped with a MCT detector. Before a measurement, the sample (30.0 $\mathrm{mg}$ ) was pressed into a thin disk with a diameter of $13 \mathrm{~mm}$ and was treated at $200{ }^{\circ} \mathrm{C}$ under high-vacuum conditions $\left(5-8 \times 10^{-2} \mathrm{~Pa}\right)$ to remove the adsorbed water and the volatile organics. After cooling to $30{ }^{\circ} \mathrm{C}$, $\mathrm{CO}_{2}$ and isobutane were introduced for $30 \mathrm{~min}$. Finally, the sample was heated to different temperatures and IR spectra with a resolution of $2 \mathrm{~cm}^{-1}$ were collected by accumulating 64 scans.

\subsection{Reaction procedure}

The catalytic experiments were performed in a stainless steel fixed bed reactor (i. d. $=6 \mathrm{~mm}$ ). Typically, $200 \mathrm{mg}$ catalyst (40-60 mesh) was loaded into the reactor, and it was heated to $600{ }^{\circ} \mathrm{C}$ under a flow of $\mathrm{N}_{2}$. A flow of $\mathrm{CO}_{2}$ (or $\mathrm{N}_{2}$ ) and isobutane that was separately calibrated using mass flow controllers was then applied and the reaction began under the following conditions at $600{ }^{\circ} \mathrm{C}$, and the $\mathrm{CO}_{2}\left(\mathrm{~N}_{2}\right) / \mathrm{C}_{4} \mathrm{H}_{10}$ (molar ratio) was 5 . The gas hourly space velocity (GHSV) with respect to isobutane was $1500 \mathrm{~mL} \cdot \mathrm{g}^{-1} \cdot \mathrm{h}^{-1}$. The effluent products were analyzed using an on-line gas chromatograph (Shimadzu GC-14C) equipped with a FID and an alumina packed column.

\section{Results and discussion}

\section{1. $\mathrm{CO}_{2}-\mathrm{ODB}$ over different catalysts}

Under the reaction conditions used, the blank experiment showed an isobutane conversion of less than $2 \%$, indicating negligible thermal reactions. The results for the $\mathrm{CO}_{2}$-ODB using different oxides are shown in Fig. 1. During the initial reaction stage, the conversion of isobutane decreased as follows: $\mathrm{V}_{2} \mathrm{O}_{5}$ $>>\mathrm{CeO}_{2}>\mathrm{ZrO}_{2}>\mathrm{Al}_{2} \mathrm{O}_{3}$. This indicates that bulk $\mathrm{V}_{2} \mathrm{O}_{5}$ is more active than $\mathrm{CeO}_{2}$ or $\mathrm{ZrO}_{2}$ for the $\mathrm{CO}_{2}-\mathrm{ODB}$. However, after a time-on-stream (TOS) of about $3 \mathrm{~h}$, a very similar conversion of isobutane was observed for all the oxides, indicating very fast deactivation of the bulk $\mathrm{V}_{2} \mathrm{O}_{5}$ during the titled reaction. As far as the products are concerned, the steady selectivity of the total $\mathrm{C}_{4}$ olefins (mainly isobutene) over $\mathrm{V}_{2} \mathrm{O}_{5}(86 \%)$ and $\mathrm{ZrO}_{2}(81 \%)$ was very similar and was much higher than that over $\mathrm{CeO}_{2}$ $(33 \%)$ and $\mathrm{Al}_{2} \mathrm{O}_{3}(60 \%)$.

The TOS results of the ODB over the $6 \mathrm{wt} \% \mathrm{~V}_{2} \mathrm{O}_{5}$-supported catalysts are given in Fig. 2. By comparison with the results of

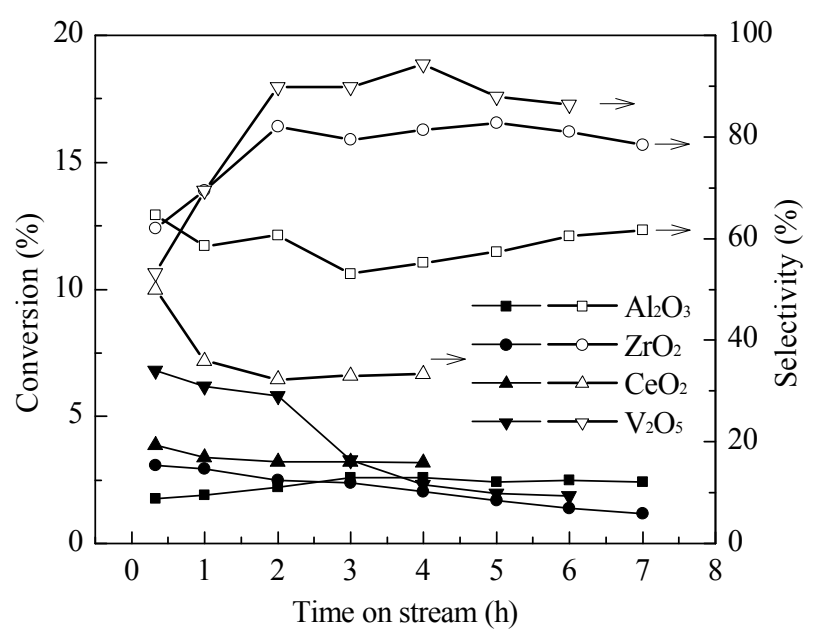

Fig. 1. Time-on-stream iso- $\mathrm{C}_{4} \mathrm{H}_{10}$ conversion and selectivity toward total $\mathrm{C}_{4}$ olefins over different oxides.

bulk $\mathrm{V}_{2} \mathrm{O}_{5}$ (Fig. 1), a significant increase in the initial conversion of isobutane was observed over the $\mathrm{V}_{2} \mathrm{O}_{5}$-supported catalysts. Moreover, a compositional effect of the support materials on the initial isobutane conversion was clear, i.e., $19.6 \%, 17.2 \%$, and $16.5 \%$ at a TOS of $0.33 \mathrm{~h}$ for $6 \mathrm{wt} \% \mathrm{~V}_{2} \mathrm{O}_{5} / \mathrm{CZA}, 6 \mathrm{wt} \%$ $\mathrm{V}_{2} \mathrm{O}_{5} / \mathrm{ZrO}_{2}(7 \mathrm{wt} \%)-\mathrm{Al}_{2} \mathrm{O}_{3}$, and $6 \mathrm{wt} \% \mathrm{~V}_{2} \mathrm{O}_{5} / \mathrm{CeO}_{2}(7 \mathrm{wt} \%)-\mathrm{Al}_{2} \mathrm{O}_{3}$, respectively. Compared with the reported results of experiments carried out under similar conditions, the $6 \mathrm{wt} \%$ $\mathrm{V}_{2} \mathrm{O}_{5} / \mathrm{CZA}$ showed higher catalytic activity toward the titled reaction. However, increasing the TOS to $7 \mathrm{~h}$ resulted in all of the catalysts a quick decrease in isobutane conversion, and a relatively more stable performance was obtained over the 6 wt $\% \mathrm{~V}_{2} \mathrm{O}_{5} / \mathrm{CZA}$. As far as product compositions are concerned, all the catalysts gave a similar high selectivity towards the desired olefin. Moreover, the selectivity toward total $\mathrm{C}_{4}$ olefins increased slightly from $\sim 86 \%$ to $\sim 91 \%$ with an increase in the TOS from 0.33 to $7 \mathrm{~h}$.

The impact of vanadia loading over $\mathrm{V}_{2} \mathrm{O}_{5} / \mathrm{CZA}$ on the performance of $\mathrm{CO}_{2}$-ODB is shown in Fig. 3. All the vanadia-loaded catalysts showed very similar selectivity toward total $\mathrm{C}_{4}$ olefins ( 90\%), which is much higher than that without vanadia

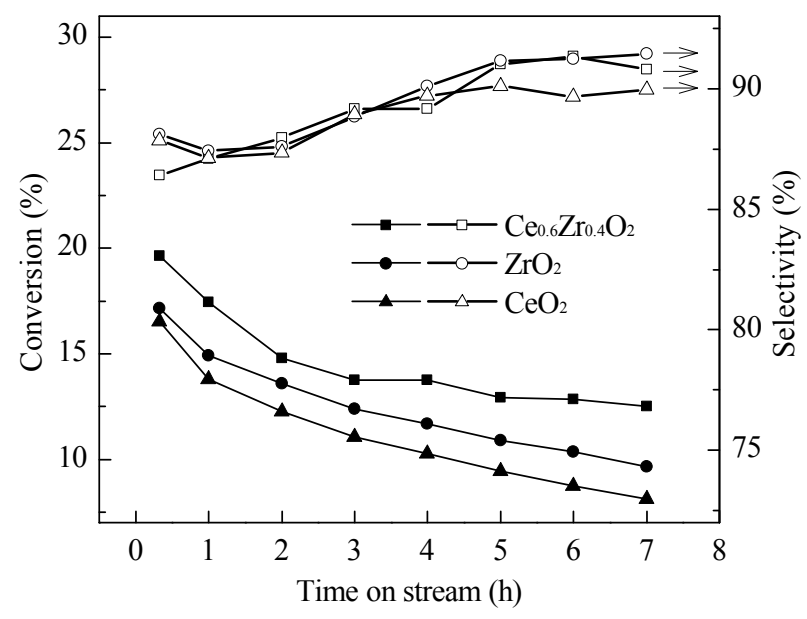

Fig. 2. Time-on-stream iso- $\mathrm{C}_{4} \mathrm{H}_{10}$ conversion and selectivity toward total $\mathrm{C}_{4}$ olefins over different catalysts. 


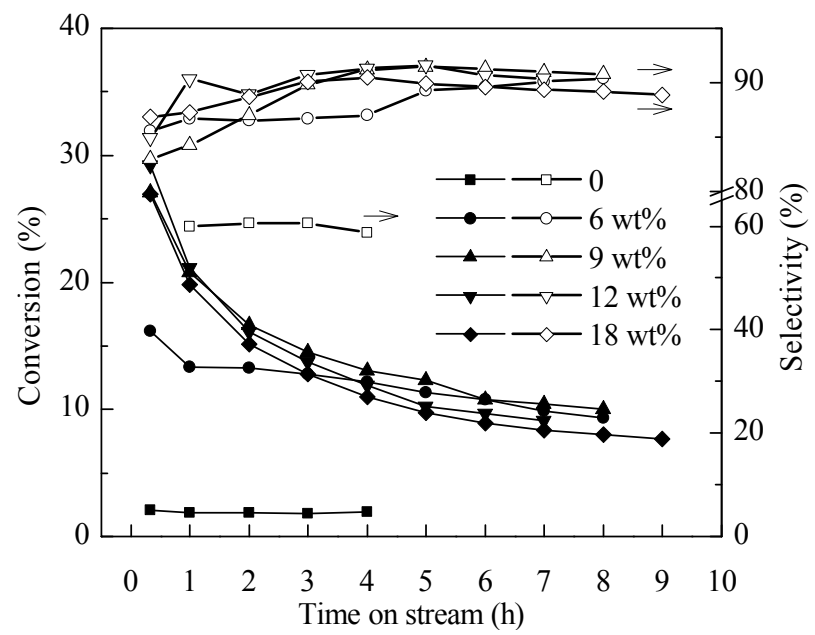

Fig. 3. Effect of vanadia loading over $\mathrm{V}_{2} \mathrm{O}_{5} / \mathrm{Ce}_{0.6} \mathrm{Zr}_{0.4} \mathrm{O}_{2}(7 \mathrm{wt} \%)-\mathrm{Al}_{2} \mathrm{O}_{3}$ on the time-on-stream iso- $\mathrm{C}_{4} \mathrm{H}_{10}$ conversion and selectivity toward total $\mathrm{C}_{4}$ olefins.

$(\sim 60 \%)$. This clearly indicates the negligible influence of vanadia loading toward targeted product selectivity, which confirms the benefits of $\mathrm{CO}_{2}$ as a soft oxidant $[8,9]$. With an increase in vanadia loading from 0 to $9 \mathrm{wt} \%$, the conversion of isobutane during the initial reaction stage of $0.33 \mathrm{~h}$ increased significantly. This indicated that the vanadium species are active sites for the titled reaction. Moreover, a further increase in vanadia loading to $12 \mathrm{wt} \%$ led to a slight increase in isobutane conversion. A slight decrease in isobutane conversion was obtained when the vanadia loading was $18 \mathrm{wt} \%$. Irrespective of the vanadia loading, almost the same conversion of isobutane $(\sim 13 \%-14 \%)$ was obtained at a TOS of $3 \mathrm{~h}$ and a limited decrease was evident until the end of the tests. This may be caused by fast coke deposition over the catalysts, which will be discussed later with the characterization results of the used catalysts.

To determine the effect of $\mathrm{Ce}_{0.6} \mathrm{Zr}_{0.4} \mathrm{O}_{2}-\mathrm{Al}_{2} \mathrm{O}_{3}$ composition on catalytic performance, the $6 \mathrm{wt} \% \mathrm{~V}_{2} \mathrm{O}_{5}$-supported $\mathrm{Ce}_{0.6} \mathrm{Zr}_{0.4} \mathrm{O}_{2}$ (5 wt\%)- $\mathrm{Al}_{2} \mathrm{O}_{3}, \mathrm{Ce}_{0.6} \mathrm{Zr}_{0.4} \mathrm{O}_{2}(7 \mathrm{wt} \%)-\mathrm{Al}_{2} \mathrm{O}_{3}$, and $\mathrm{Ce}_{0.6} \mathrm{Zr}_{0.4} \mathrm{O}_{2}$ (9 wt\%) $-\mathrm{Al}_{2} \mathrm{O}_{3}$ catalysts were subjected to the $\mathrm{CO}_{2}$-ODB and the TOS results are given in Fig. 4. As expected, a higher than $90 \%$ selectivity of total $\mathrm{C}_{4}$ olefins was obtained over all of the catalysts, indicating the negligible effect of the amount of $\mathrm{Ce}_{0.6} \mathrm{Zr}_{0.4} \mathrm{O}_{2}$. However, the 6 wt $\% \quad \mathrm{~V}_{2} \mathrm{O}_{5} / \mathrm{Ce}_{0.6} \mathrm{Zr}_{0.4} \mathrm{O}_{2}(7$ $\mathrm{wt} \%)-\mathrm{Al}_{2} \mathrm{O}_{3}$ showed slightly higher activity and stability toward $\mathrm{CO}_{2}$-ODB than the remaining catalysts.

The TOS results for the $\mathrm{CO}_{2}$-ODB over VCZA are shown in Fig. 5. For catalysts with the same composition (Figs. 3 and 5), the difference in selectivity toward total $\mathrm{C}_{4}$ olefins was negligible. However, a significant impact on the activity and stability was found by using different vanadia loading methods. As indicated in Figs. 3 and 5, VCZA gave a clearly lower initial conversion of isobutane than $\mathrm{V}_{2} \mathrm{O}_{5} / \mathrm{CZA}$ with the same vanadia loading. On the contrary, more stable performance was observed over VCZA than over $\mathrm{V}_{2} \mathrm{O}_{5} / \mathrm{CZA}$, and 9-VCZA gave the highest performance throughout the test.

From these catalytic results, it is obvious that vanadium species are the active sites for $\mathrm{CO}_{2}-\mathrm{ODB}$, and the activity and

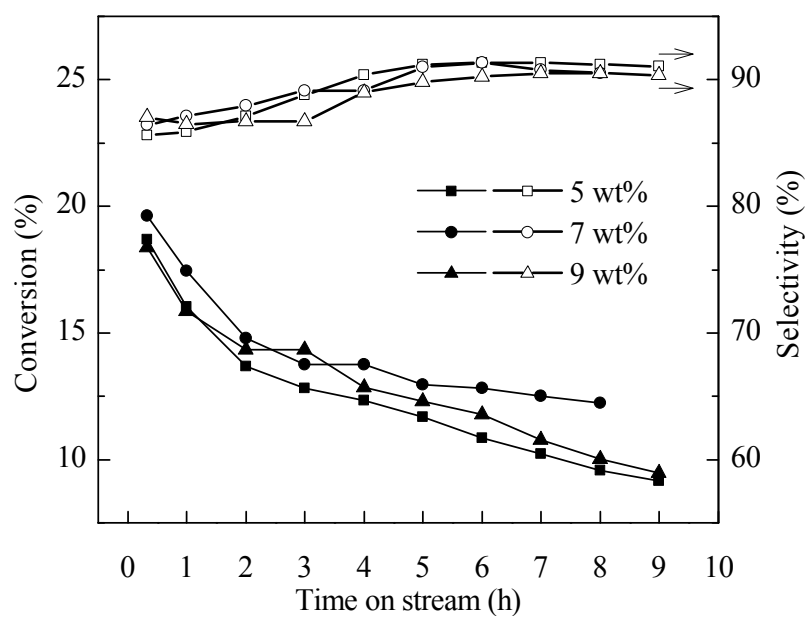

Fig. 4. Effect of $\mathrm{Ce}_{0.6} \mathrm{Zr}_{0.4} \mathrm{O}_{2}$ content on the time-on-stream iso- $\mathrm{C}_{4} \mathrm{H}_{10}$ conversion and selectivity toward total $\mathrm{C}_{4}$ olefins over $6 \mathrm{wt} \%$ $\mathrm{V}_{2} \mathrm{O}_{5} / \mathrm{Ce}_{0.6} \mathrm{Zr}_{0.4} \mathrm{O}_{2}-\mathrm{Al}_{2} \mathrm{O}_{3}$.

stability of the vanadia-based catalysts are promoted by the method of $\mathrm{V}_{2} \mathrm{O}_{5}$ introduction and the addition of $\mathrm{CeO}_{2}, \mathrm{ZrO}_{2}$, and $\mathrm{Ce}_{0.6} \mathrm{Zr}_{0.4} \mathrm{O}_{2}$, the extent of which is obviously dependent on their content. Moreover, all of the vanadia-loaded catalysts showed relatively fast deactivation from the start of the reaction to a TOS of $\sim 3 \mathrm{~h}$, and this leveled off until the end of the test. On the contrary, all of the catalysts showed high selectivity toward total $\mathrm{C}_{4}$ olefins $(\sim 90 \%)$, which matches the benefits of the $\mathrm{CO}_{2}$-ODB well. In the next section, the activity and stability results of the $\mathrm{CO}_{2}$-ODB over the vanadia-based catalysts will be related to the characterization results of the materials.

\subsection{Insights into the catalytic behaviour of the vanadia-based catalysts}

It is commonly known that crystalline $\mathrm{V}_{2} \mathrm{O}_{5}$ is less active in oxidative dehydrogenation reactions as a result of its platelet morphology and its inactive basal planes [36,37]. As a result, vanadia is generally dispersed over oxides such as alumina to inhibit the formation of well-crystallized $\mathrm{V}_{2} \mathrm{O}_{5}$. Thus, highly

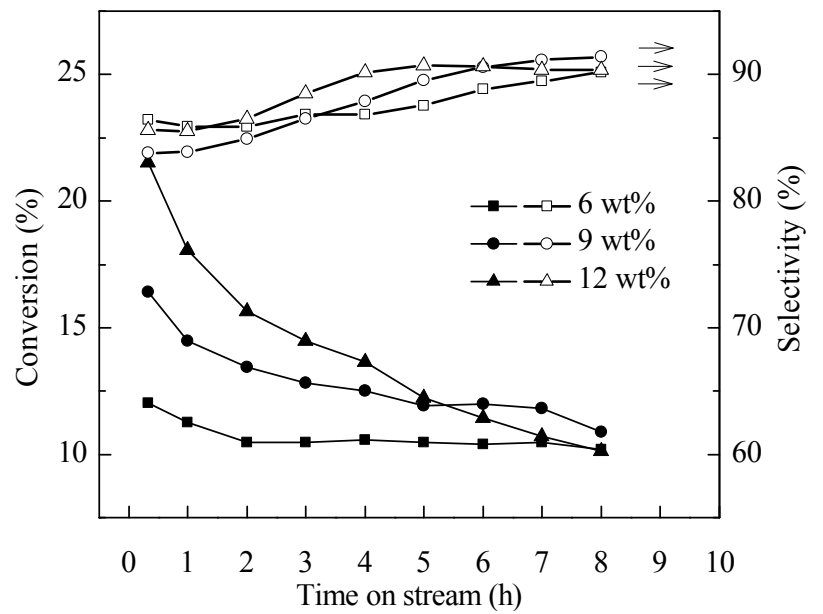

Fig. 5. Effect of $\mathrm{V}_{2} \mathrm{O}_{5}$ loading on the performance of $\mathrm{V}_{2} \mathrm{O}_{5}-\mathrm{Ce}_{0.6} \mathrm{Zr}_{0.4} \mathrm{O}_{2}(7$ wt $\%)-\mathrm{Al}_{2} \mathrm{O}_{3}$ for $\mathrm{CO}_{2}$-ODB. 
dispersed vanadium species that have not formed crystalline $\mathrm{V}_{2} \mathrm{O}_{5}$ are responsible for the $\mathrm{CO}_{2}-\mathrm{ODB}$ activity of the $\mathrm{V}_{2} \mathrm{O}_{5}$-supported catalysts. To give a insight into the varied performance of $\mathrm{V}_{2} \mathrm{O}_{5}$-based catalysts for the $\mathrm{CO}_{2}-\mathrm{ODB}$, the materials were characterized by $\mathrm{N}_{2}$ adsorption-desorption at $-196^{\circ} \mathrm{C}$ and XRD.

The BET surface areas of typical materials are listed in Table 1. It was shown that the BET surface area of $\mathrm{V}_{2} \mathrm{O}_{5}$ synthesized by the sol-gel method was very low, which may be due to the high degree of crystallization. In the case of alumina, a very high BET surface area $\left(>400 \mathrm{~m}^{2} \cdot \mathrm{g}^{-1}\right)$ was obtained. Compared with $\mathrm{Al}_{2} \mathrm{O}_{3}$, the BET surface area of the $6 \mathrm{wt} \% \mathrm{~V}_{2} \mathrm{O}_{5}$-supported catalysts was significantly lower and this is slightly dependent on the presence of ceria and zirconia, or their solid solution. When the BET surface areas of the catalysts were related to the conversion of isobutane, no simple relationship was evident. This indicates its relevant insignificance in determining the activity of the catalysts in the titled reaction.

The XRD patterns of the materials are given in Fig. 6. For all of the samples, the peak intensity of the XRD diffractions was very low, indicating a low extent of crystallization for all the phases in the samples. Specifically, in the case of the alumina synthesized by the sol-gel method, low crystalline $\gamma-\mathrm{Al}_{2} \mathrm{O}_{3}$ was evident from the clear (440) diffraction at a $2 \theta$ of about $66^{\circ}$ and the very broad (400) diffraction. In the case of CZA, the addition of $7 \mathrm{wt} \% \mathrm{Ce}_{0.6} \mathrm{Zr}_{0.4} \mathrm{O}_{2}$ to $\mathrm{Al}_{2} \mathrm{O}_{3}$ resulted in very limited changes to the XRD pattern, indicating the high dispersion and low crystallinity of $\mathrm{Ce}_{0.6} \mathrm{Zr}_{0.4} \mathrm{O}_{2}$. Moreover, a weak diffraction assigned to cubic ceria was observed for the $6 \mathrm{wt} \% \mathrm{~V}_{2} \mathrm{O}_{5} / \mathrm{CeO}_{2}(7$ wt\%)- $\mathrm{Al}_{2} \mathrm{O}_{3}$. For all of the $\mathrm{V}_{2} \mathrm{O}_{5}$-loaded samples up to $18 \mathrm{wt} \%$ $\mathrm{V}_{2} \mathrm{O}_{5}$, no vanadium species were detectable by XRD, indicating its highly dispersed state. When the XRD patterns of $\mathrm{V}_{2} \mathrm{O}_{5} / \mathrm{CZA}$ were compared with those of VCZA, no difference was found except for a slight decrease in the peak intensity of the (440) diffraction of $\gamma-\mathrm{Al}_{2} \mathrm{O}_{3}$. Thus, irrespective of the vanadia content over all of the catalysts, the formation of crystalline $\mathrm{V}_{2} \mathrm{O}_{5}$ was not evident. This can be used to explain the high activity of the vanadia-based catalysts in the $\mathrm{CO}_{2}$-ODB. Moreover, the catalytic activity varied with vanadia loading and the effect of method of introduction can be well explained by the dispersion of the monomeric and/or polymeric $\mathrm{VO}_{x}$ species, and this has been

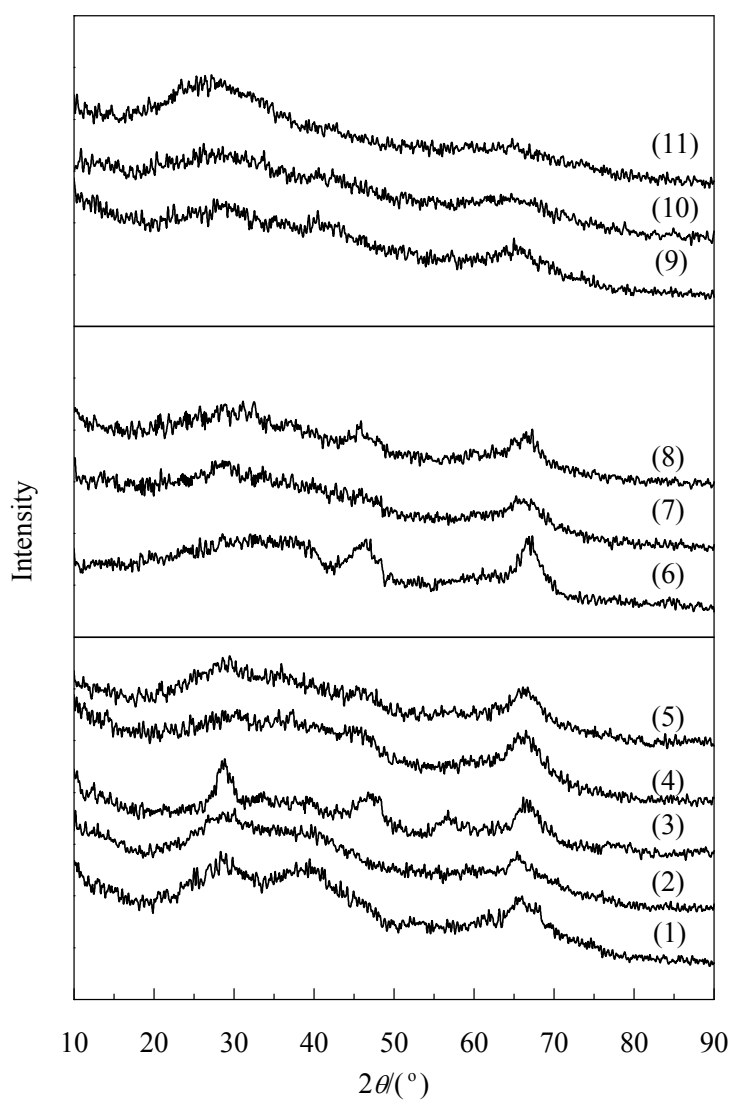

Fig. 6. $\mathrm{XRD}$ patterns of $\mathrm{Al}_{2} \mathrm{O}_{3}$ (1), $\mathrm{CZA}$ (2), $6 \mathrm{wt} \% \mathrm{~V}_{2} \mathrm{O}_{5} / \mathrm{CeO}_{2}(7$ wt\%)- $\mathrm{Al}_{2} \mathrm{O}_{3}$ (3), 6 wt $\% \mathrm{~V}_{2} \mathrm{O}_{5} / \mathrm{ZrO}_{2}$ (7 wt\%)- $\mathrm{Al}_{2} \mathrm{O}_{3}$ (4), 6 wt $\% \mathrm{~V}_{2} \mathrm{O}_{5} / \mathrm{CZA}$ (5), $9 \mathrm{wt} \% \mathrm{~V}_{2} \mathrm{O}_{5} / \mathrm{CZA}(6), 12 \mathrm{wt} \% \mathrm{~V}_{2} \mathrm{O}_{5} / \mathrm{CZA}(7), 18 \mathrm{wt} \% \mathrm{~V}_{2} \mathrm{O}_{5} / \mathrm{CZA}(8)$ ), 6-VCZA (9), 9-VCZA (10), 12-VCZA (11).

clearly revealed in our previous work [34,35].

It is commonly observed that coke deposition is a severe issue during the dehydrogenation of hydrocarbons with $\mathrm{CO}_{2}$, and coking plays an important role in determining the stability of the catalyst. Thus, the used catalysts were subjected to TG analyses, and the amount of coke deposited over different catalysts is given in Table 1 . It revealed that coke deposition was very severe over all of the catalysts, which agrees with previous results [38,39]. Specifically, $6 \mathrm{wt} \%$ vanadia supported catalysts

Table 1

BET surface area of the fresh oxides, the amount of coke deposited, and the deactivation rate of the different catalysts.

\begin{tabular}{|c|c|c|c|c|}
\hline \multirow{2}{*}{ Sample } & \multirow{2}{*}{ BET surface area $\left(\mathrm{m}^{2} \mathrm{~g}^{-1}\right)$} & \multicolumn{2}{|c|}{ Coke $^{a}$} & \multirow{2}{*}{ Deactivation ${ }^{\mathrm{b}}(\%)$} \\
\hline & & (wt $\%)$ & $\mathrm{mg} \mathrm{mol}^{-1}$ & \\
\hline $\mathrm{Al}_{2} \mathrm{O}_{3}$ & 441 & - & - & - \\
\hline $\mathrm{CeO}_{2}$ & 49 & - & - & - \\
\hline $\mathrm{ZrO}_{2}$ & 17 & - & - & - \\
\hline $\mathrm{V}_{2} \mathrm{O}_{5}$ & 4 & - & - & - \\
\hline $6 \mathrm{wt} \% \mathrm{~V}_{2} \mathrm{O}_{5} / \mathrm{CeO}_{2}(7 \mathrm{wt} \%)-\mathrm{Al}_{2} \mathrm{O}_{3}$ & 210 & 18.1 & 3.47 & 50.9 \\
\hline $6 \mathrm{wt} \% \mathrm{~V}_{2} \mathrm{O}_{5} / \mathrm{ZrO}_{2}(7 \mathrm{wt} \%)-\mathrm{Al}_{2} \mathrm{O}_{3}$ & 279 & 21.2 & 3.63 & 43.6 \\
\hline $6 \mathrm{wt} \% \mathrm{~V}_{2} \mathrm{O}_{5} / \mathrm{CZA}$ & 221 & 21.6 & 3.18 & 36.2 \\
\hline 6-VCZA & - & 22.6 & 3.20 & 15.0 \\
\hline 9-VCZA & - & 21.8 & 3.97 & 33.5 \\
\hline
\end{tabular}

a The coke deposited over the catalysts used was determined by TG analyses, and was expressed as weight percentage over the catalyst (wt\%) and as the weight of the deposited coke required to convert $1 \mathrm{~mol}$ of isobutane $\left(\mathrm{mg} \mathrm{mol}^{-1}\right)$.

b Deactivation of the catalyst for $\mathrm{CO}_{2}-\mathrm{ODB}=\frac{\left(\mathrm{Con}_{\mathrm{C} 4 \mathrm{H} 10}\right)_{\mathrm{i}}-\left(\mathrm{Con}_{\mathrm{C} 4 \mathrm{H} 10}\right)_{\mathrm{f}}}{\left(\mathrm{Con}_{\mathrm{C} 4 \mathrm{H} 10}\right)_{\mathrm{i}}} \times 100 \%$. 
produced a lower amount of coke while 6-VCZA gave the highest amount of coke (22.6 wt\%), indicating the significant effect of catalyst preparation method on its coking behavior during the $\mathrm{CO}_{2}$-ODB. To quantitatively compare the deactivation of the different catalysts in the titled reaction, the deactivation rate was calculated and the results are shown in Table 1 . When the amount of coke deposited was correlated to the deactivation rate of the catalysts no simple relationship was found. Moreover, the coke deposited by the conversion of $1 \mathrm{~mol}$ isobutane over the catalyst could not be related to the deactivation rate of the catalyst. Thus, the amount of coke was not the main reason for the deactivation of the catalyst although severe coking occurred over all of the catalysts. To determine the reason, $\mathrm{O}_{2}$-TPO was carried out on selected catalysts after the reaction and the results are given in Fig. 7. From Table 1 and Fig. 7, the amount of coke deposited over the used 6-VCZA and 9-VCZA was similar, and the peak temperature of the $\mathrm{O}_{2}$-TPO profiles was almost the same $\left(500{ }^{\circ} \mathrm{C}\right)$. However, the $\mathrm{O}_{2}$-TPO profile of 9 -VCZA spanned a much wider range of temperatures than that of 6-VCZA, i.e., a clearly higher starting temperature $\left(\sim 50^{\circ} \mathrm{C}\right)$ and a much higher end temperature $\left(100^{\circ} \mathrm{C}\right)$. As a result, the coke deposited over 9-VCZA was much heavier (lower H/C ratio) than that over 6-VCZA, leading to an enhanced deactivation for the titled reaction. Thus, the quantity of heavier coke deposited is responsible for the deactivation of the catalyst in the $\mathrm{CO}_{2}$-ODB.

\subsection{Mechanistic aspects of the $\mathrm{CO}_{2}-\mathrm{ODB}$}

The advantages of $\mathrm{CO}_{2}$-ODB are clearly related to the catalyst as explained previously by two different proposed pathways [11]. To determine the reaction mechanism, the transient kinetic behavior of isobutane dehydrogenation in the presence of $\mathrm{N}_{2}$ and $\mathrm{CO}_{2}$ was comparatively investigated over the vanadia-based catalysts, and TPSR results of the molecular ions at $m / z$ of $43[\mathrm{M}-15]^{+}, 56[\mathrm{M}]^{+}, 44[\mathrm{M}]^{+}$, and $28[\mathrm{M}]^{+}$are given in Fig. 8.

In the case of 6-VCZA (Fig. 8a), the starting temperature for the consumption of isobutane under a $\mathrm{CO}_{2}$ atmosphere $\left(\sim 460^{\circ} \mathrm{C}\right)$ was significantly lower than that under a $\mathrm{N}_{2}$ atmosphere

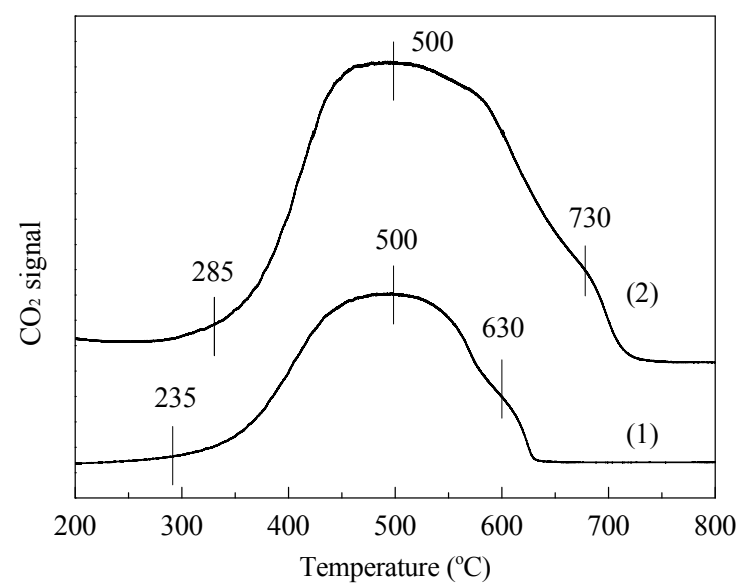

Fig. 7. Mass spectra of $\mathrm{CO}_{2}$ during the $\mathrm{O}_{2}$-TPO using 6-VCZA (1) and 9-VCZA (2).

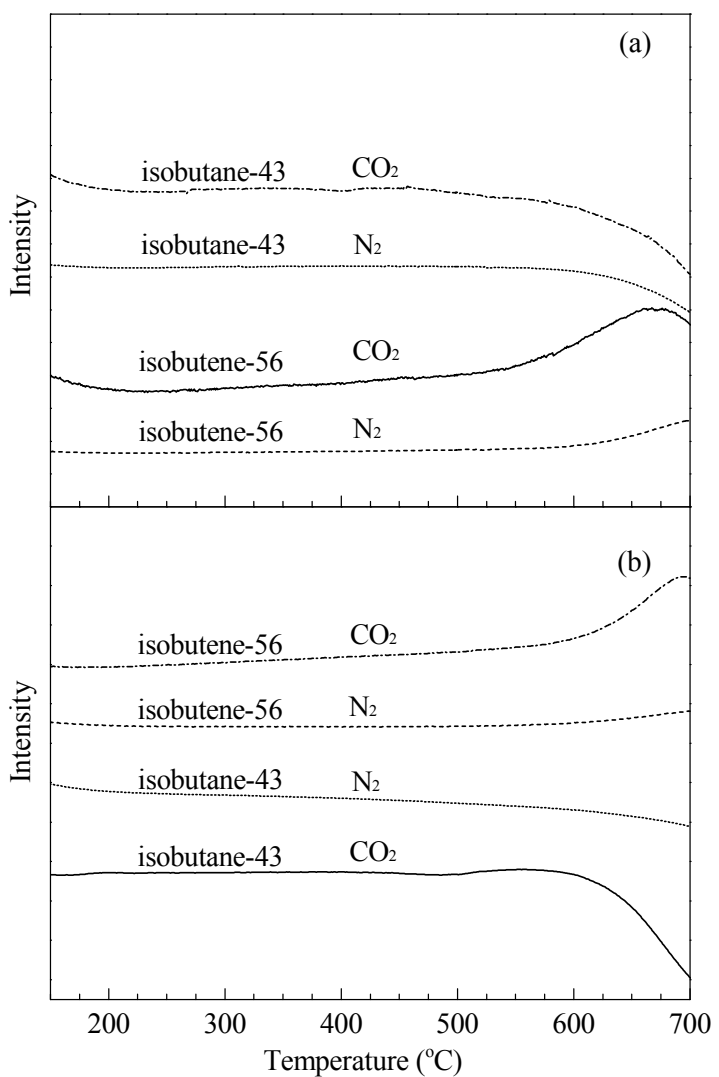

Fig. 8. Mass spectra of the TPSR results for the dehydrogenation of isobutane under an atmosphere of $\mathrm{N}_{2}$ and $\mathrm{CO}_{2}$ over 6-VCZA (a) and 9-VCZA (b).

$\left(\sim 560^{\circ} \mathrm{C}\right)$. The formation of isobutene was clearly observed in both cases. However, with an increase in temperature, the changing pattern indicating the consumption of isobutane and the formation of isobutene in the presence of $\mathrm{CO}_{2}$ was quite different from those in the presence of $\mathrm{N}_{2}$. In the presence of $\mathrm{CO}_{2}$, the consumption of isobutane and the formation of isobutene were more pronounced than that in the presence of $\mathrm{N}_{2}$. Moreover, a significant peak at about $670^{\circ} \mathrm{C}$ was observed under a $\mathrm{CO}_{2}$ atmosphere. On the contrary, a slight but continuous increase in the content of isobutene was obtained under a $\mathrm{N}_{2}$ atmosphere. As far as the results for 9-VCZA are concerned, the mentioned observations were still valid. Thus, irrespective of the catalyst the benefits of dehydrogenation over vanadia-based catalysts in the presence of $\mathrm{CO}_{2}$ are obvious compared with direct dehydrogenation under an inert atmosphere such as $\mathrm{N}_{2}$.

To determine the mechanism of the $\mathrm{CO}_{2}$ - $\mathrm{ODB}$ upon catalysis by vanadia-based catalysts, in situ FTIR was performed at different temperatures and the results are given in Fig. 9. The vibrational peaks (Fig. 9(b)) at about 2966, 2953, and 2917 $\mathrm{cm}^{-1}$ are clearly visible at room temperature, and they can be assigned to the stretching vibrations of saturated $-\mathrm{C}-\mathrm{H}$ bonds $(v(-\mathrm{C}-\mathrm{H}))$ in $\mathrm{C}_{4} \mathrm{H}_{10}$. With an increase in temperature to $450{ }^{\circ} \mathrm{C}$ those peaks decreased by a different extent. Furthermore, when the temperature was increased to $400{ }^{\circ} \mathrm{C}$, a stretching vibration absorption of unsaturated $=\mathrm{C}-\mathrm{H}$ bonds $(v(=\mathrm{C}-\mathrm{H}))$ at about $3017 \mathrm{~cm}^{-1}$ appeared and increased with an increase in 

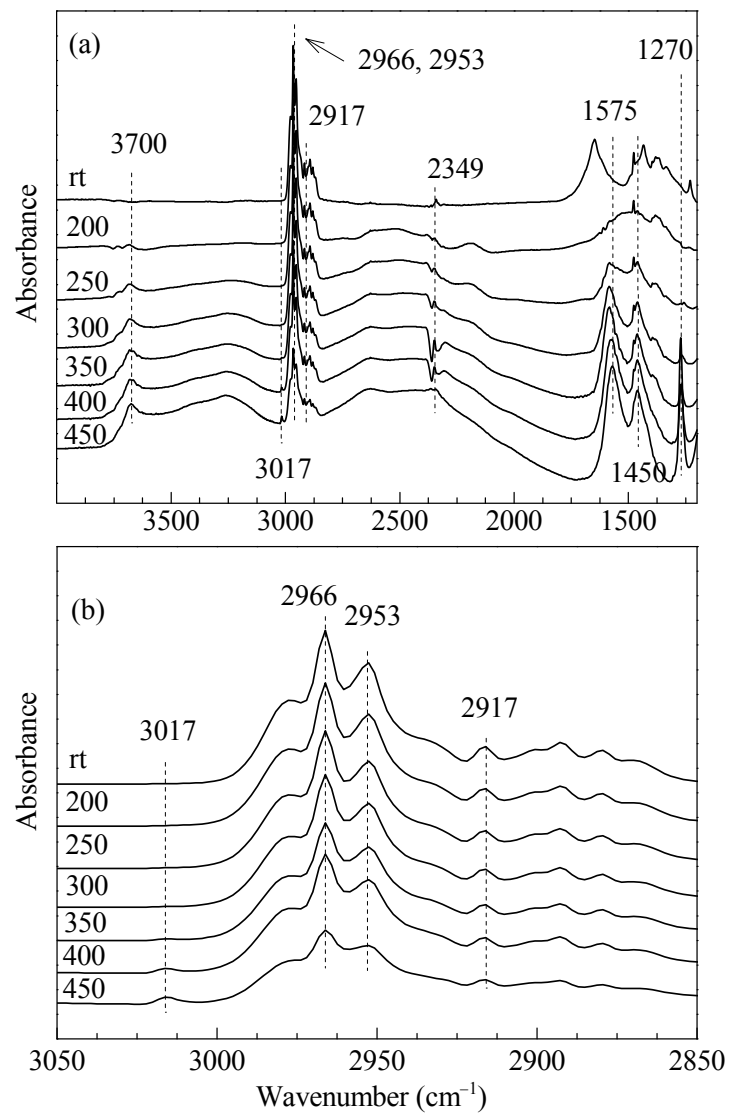

Fig. 9. In situ FTIR spectra upon the $\mathrm{CO}_{2}-\mathrm{ODB}$ at different temperatures over 6-VCZA from 4000-1200 $\mathrm{cm}^{-1}$ (a) and 3050-2850 $\mathrm{cm}^{-1}$ (b).

temperature. The production of butene under these reaction conditions is clear. A further increase in the temperature to $450{ }^{\circ} \mathrm{C}$ led to the disappearance of the asymmetric stretching vibration absorption of $\mathrm{CO}_{2}\left(\mathrm{~V}_{\mathrm{as}}\left(\mathrm{CO}_{2}\right)\right)$ located at about $2349 \mathrm{~cm}^{-1}$. The adsorption of $\mathrm{CO}_{2}$ onto the surface of the catalysts was also affected by the temperature. More importantly, when the temperature was higher than $350{ }^{\circ} \mathrm{C}$, two peaks at about 3700 and $1270 \mathrm{~cm}^{-1}$ appeared, and these can be assigned to stretching vibrations of the $-\mathrm{O}-\mathrm{H}$ bonds $(v(-\mathrm{O}-\mathrm{H}))[40]$ and the $\mathrm{C}-0$ bonds $(v(\mathrm{C}-\mathrm{O}))[41]$, respectively. This demonstrates that isobutane reacted with $\mathrm{CO}_{2}$ to form intermediates at those temperatures, and this is significantly different from the coupled mechanisms of direct dehydrogenation and reverse water-gas-shift reactions. Therefore, it is reasonable to propose that the $\mathrm{CO}_{2}-\mathrm{ODB}$ over the vanadia-based catalysts follows the Mars-van Krevelen redox mechanism.

\section{Conclusions}

In summary, vanadia-based catalysts were successfully synthesized by using the sol-gel method, and found to be highly active for the $\mathrm{CO}_{2}$-ODB. All of the catalysts showed over $85 \%$ selectivity toward total $\mathrm{C}_{4}$ olefins. The highly dispersed and low crystallinity $\mathrm{VO}_{x}$ species were found to be the active sites for the titled reaction. Thus, the catalytic activity was significantly influenced by the composition of the catalysts and the intro- ducing method of $\mathrm{V}_{2} \mathrm{O}_{5}$, and the highest initial conversion of isobutane was obtained over $12 \mathrm{wt} \% \mathrm{~V}_{2} \mathrm{O}_{5} / \mathrm{CZA}$. The deactivation of the catalyst was mainly caused by the deposition of the heavier coke, and the titled reaction followed the Mars-van Krevelen redox mechanism.

\section{References}

[1] Iannazzo V, Neri G, Galvagno S, Di Serio, M, Tesser R, Santacesaria E. Appl Catal A, 2003, 246: 49

[2] Pozan G S, Tavman A, Boz I. Chem Eng J, 2008, 143: 180

[3] Wang G W, Li C Y. Shan H H. ACS Catal, 2014: 1139

[4] He M Y, Hu Z Q, Xiao B, Li J F, Guo X J, Luo S Y, Yang F, Feng Y, Yang G J, Liu S M. Int J Hydrogen Energy, 2009, 34: 195

[5] Liang C D, Xie H, Schwartz V, Howe J, Dai S, Overbury S H. J Am Chem Soc, 2009, 131: 7735

[6] Ovsitser O, Kondratenko E V. Chem Commun, 2010, 46: 4974

[7] Wang G Z, Zhang L, Deng J G, Dai H X, He H, Au C T. Appl Catal A, 2009, 355: 192

[8] Ansari M B, Park S E. Energy Environ Sci, 2012, 5: 9419

[9] Wang S B, Zhu Z H. Energy Fuels, 2004, 18: 1126

[10] Ajayi B P, Rabindran Jermy B, Abussaud B A, Al-Khattaf S. J Porous Mater, 2013, 20: 1257

[11] Ajayi B P, Jermy B R, Ogunronbi K E, Abussaud B A, Al-Khattaf S. Catal Today, 2013, 204: 189

[12] He X X, Fan C, Gu X Y, Zhou X G, Chen D, Zhu Y A. J Mol Catal A Chem, 2011, 344: 53

[13] Michorczyk P, Pietrzyk P, Ogonowski J. Microporous Mesoporous Mater, 2012, 161: 56

[14] Nederlof C, Talay G, Kapteijn F, Makkee M. Appl Catal A, 2012, 423-424, 59

[15] Raju G, Reddy B M, Abhishek B, Mo Y H, Park S E. Appl Catal A, 2012, 423-424: 168

[16] Rao R C, Zhang Q Y, Liu H D, Yang H X, Ling Q Yang M, Zhang A M, Chen W.J Mol Catal A, 2012, 363-364: 283

[17] Shishido T, Shimamura K, Teramura K, Tanaka T. Catal Today, 2012, 185: 151

[18] Wang Q, Li X H, Li W Y, Feng J. Catal Commun, 2014, 50: 21

[19] Wu R X, Xie P F, Cheng Y H, Yue Y H, Gu S Y, Yang W M, Miao C X, Hua W M, Gao Z. Catal Commun, 2013, 39: 20

[20] Yan W, Kouk Q Y, Luo J Z, Liu Y, Borgna A. Cataly Commun, 2014, 46: 208

[21] Ding J F, Qin Z F, Li X K, Wang G F, Wang J G. J Mol Catal A, 2010, 315: 221

[22] Ogonowski J, Skrzyńska E. Catal Commun, 2009, 11: 132

[23] Ogonowski J, Skrzyńska E. React Kinet Catal Lett, 2006, 88: 293

[24] Wang G Z, Dai H X, Zhang L, Deng J G, Liu C X, He H, Au C T. Appl Catal A, 2010, 375: 272

[25] Raju G, Reddy B M, Park S E. J CO ${ }_{2}$ Utilization, 2014, 5: 41

[26] Reddy B M, Han D S, Jiang N Z, Park S E. Catal Surv Asia, 2008, 12: 56

[27] Coperet C. Chem Rev, 2009, 110: 656

[28] Takita Y, Sano K I, Muraya T, Nishiguchi H, Kawata N, Ito M, Akbay T, Ishihara T. Appl Catal A, 1998, 170: 23

[29] Aouissi A, Aldhayan D, Alkahtani S. Chin J Catal (催化学报), 2012, 33: 1474

[30] Chen M, Wu J L, Liu Y M, Cao Y, Guo L, He H Y, Fan K N. Appl Catal A, 2011, 407: 20

[31] Bi Y L, Zhen K J, Valenzuela R X, Jia M J, Cortés Corberán V. Catal Today, 2000, 61: 369

[32] Chen M, Xu J, Liu Y M, Cao Y, He H Y, Zhuang J H. Appl Catal A, 


\title{
Graphical Abstract
}

Chin. J. Catal., 2014, 35: 1329-1336 doi: 10.1016/S1872-2067(14)60180-7

\section{Insights into the vanadia catalyzed oxidative dehydrogenation of isobutane with $\mathrm{CO}_{2}$}

Ruixue Yuan, Yang Li, Haobing Yan, Huan Wang, Jian Song, Zhongshen Zhang, Weibin Fan, Jiangang Chen, Zhongwen Liu*, Zhaotie Liu, Zhengping Hao* Shaanxi Normal University;

Research Center for Eco-Environmental Sciences, Chinese Academy of Sciences; Institute of Coal Chemistry, Chinese Academy of Sciences

The oxidative hydrogenation of isobutane with $\mathrm{CO}_{2}$ over vanadia-based catalysts was confirmed to follow the redox mechanism, and the catalyst deactivation was mainly originated from the deposition of heavier coke.

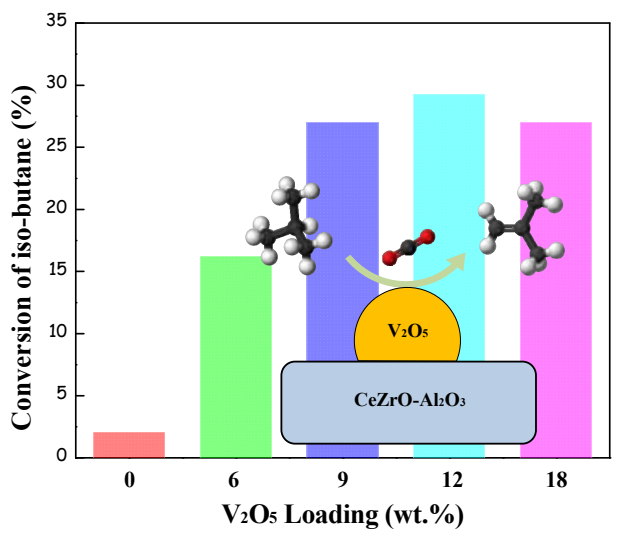

2010, 377: 35

[33] Chen M, Xu J, Cao Y, He H Y, Fan K N, Zhuang J H. J Catal, 2010, 272 : 101

[34] Liu Z W, Wang C, Fan W B, Liu Z T, Hao Q Q Long X, Lu J, Wang J G, Qin Z F, Su D S. ChemSusChem, 2011, 4: 341

[35] Wang C, Fan W B, Liu Z T, Lu J, Liu Z W, Qin Z F, Wang J G. J Mol Catal A, 2010, 329: 64

[36] Martínez-Huerta M V, Gao X, Tian H, Wachs I E, Fierro J L G, Bañares M A. Catal Today, 2006, 118: 279
[37] Wachs I E, Chen Y S, Jehng J M, Briand L E, Tanaka T. Catal Today, 2003, 78: 13

[38] Blanco S, Carrazán S R G, Rives V. Appl Catal A, 2008, $342: 93$

[39] Carniato F, Bisio C, Gatti G, Roncoroni S, Recchia S, Marchese L. Catal Lett, 2009, 131: 42

[40] Cheng C H, Lehmann J, Thies J E, Burton S D, Engelhard M H. Org Geochem, 2006, 37: 1477

[41] Sabio E, González E, González J F, González-García C M, Ramiro A, Gañan J. Carbon, 2004, 42: 2285

\section{钒氧化物催化 $\mathrm{CO}_{2}$ 氧化异丁烷脱氢的研究}

\author{
袁瑞雪 ${ }^{\mathrm{a}}$, 李 杨, 间浩兵 ${ }^{\mathrm{a}}$, 王 欢 ${ }^{\mathrm{a}}$, 宋 健 ${ }^{\mathrm{c}}$, 张中申 ${ }^{\mathrm{b}}$, 樊卫斌, 陈建刚 ${ }^{\mathrm{a}}$, \\ 刘忠文 ${ }^{\mathrm{a},{ }^{*}}$, 刘昭铁 ${ }^{\mathrm{a}}$, 郝郑平 ${ }^{\mathrm{b}, \#}$ \\ a陕西师范大学化学化工学院应用表面与胶体化学教育部重点实验室, 陕西西安710062 \\ b国科学院生态环境研究中心环境纳米材料实验室, 北京 100085 \\ ${ }^{\mathrm{c}}$ 中国科学院煤炭化学研究所煤转换国家重点实验室, 山西太原030001
}

\begin{abstract}
摘要: 采用溶胶-凝胶法制备了一系列钒氧化物催化剂, 并用于 $\mathrm{CO}_{2}$ 氧化异丁烷脱氢反应. 采用 $\mathrm{X}$ 射线衍射、低温 $\mathrm{N}_{2}$ 吸附-脱附、 $\mathrm{O}_{2}$ 程序升温氧化、程序升温表面反应和原位傅里叶变换红外光谱等方法研究了催化剂的性质. 反应结果表明, 尽管所有钒氧化物催 化剂的丁烯选择性都大于 $85 \%$, 但随着催化剂组成和制备方法的改变, 催化活性和稳定性差异显著. 其中, $12 \mathrm{wt} \%$ $\mathrm{V}_{2} \mathrm{O}_{5} / \mathrm{Ce}_{0.6} \mathrm{Zr}_{0.4} \mathrm{O}_{2}(7 \mathrm{wt} \%)-\mathrm{Al}_{2} \mathrm{O}_{3}$ 的催化活性最高, 而 $6 \mathrm{wt} \% \mathrm{~V}_{2} \mathrm{O}_{5}-\mathrm{Ce}_{0.6} \mathrm{Zr}_{0.4} \mathrm{O}_{2}(7 \mathrm{wt} \%)-\mathrm{Al}_{2} \mathrm{O}_{3}$ 的稳定性最佳. 关联分析催化反应结果 与催化剂表征表明, 钥氧化物的催化活性取决于 $\mathrm{VO}_{x}$ 物种的结晶度和分散度, 而催化剂表面所积重质焦炭的特性是决定催化剂稳 定性的关键. 非稳态反应和原位光谱结果确认, $\mathrm{CO}_{2}$ 氧化异丁烷脱氢遵循Mars-van Krevelen氧化还原机理.
\end{abstract}

关键词: 异丁烷; 氧化脱氢反应; 二氧化碳; 五氧化二钒; 三氧化二铝

收稿日期: 2014-06-21. 接受日期: 2014-06-26. 出版日期: 2014-08-20.

*通讯联系人. 电话: (029)81530801; 传真: (029)81530727; 电子信箱：zwliu@snnu.edu.cn

\#通讯联系人. 电话/传真: (010)62923564; 电子信箱: zpinghao@rcees.ac.cn

基金来源：国家重点基础研究发展计划(973计划, 2010CB732300); 国家自然科学基金(21376146, 21306111, 21337003).

本文的英文电子版由Elsevier出版社在ScienceDirect上出版(http://www.sciencedirect.com/science/journal/18722067). 